\title{
MASTER OF ENGINEERING IN BUILDING ENERGY SYSTEMS OPTION
}

\author{
Chu-Chen (C. C.) Chen \\ Chun Ling Huang \\ Department of Mechanical Engineering \\ Southern University and A\&M College
}

\begin{abstract}
Today's modern building technology encompasses a wide range of disciplines, and integrates the latest engineering technology in design, energy conservation, and energy management. Current computer technology, such as advanced building simulation software and direct digital control systems, offers the ability to operate facility systems more effectively. Energy educators, then, must develop an academic program equipped to meet the challenge of preparing students with a repertoire extensive enough to function effectively in the modern building energy industry.

This paper presents an overview of the new Master of Engineering degree in Building Energy Systems Option by the Department of Mechanical Engineering at Southern University and A\&M College. This program will address the demand of building energy managers, and energy engineers in the state of Louisiana. Our program emphasizes design, applications, laboratory experiments, and internship acquisition with a reputable engineering firm in the industry.

The Building Energy Systems curriculum includes the components of Basic Principles of Building Energy Systems, Basic Principles of Energy Conservation and Energy Management, Building System Performance Simulation Techniques, Building System Contracting Project Management, and Internships.
\end{abstract}

\section{Introduction}

As the energy educators and energy consultant in Building Energy Systems Design, the authors continue to hear concerns that energy education is still neglected at institutions of higher learning $[1,2]$. During the Tri-State Engineering Society meeting in the summer of 2002, one of our authors [3] presented a survey about the educational system in three Southern states. The findings from this survey indicated that only two of the seventeen Mechanical Engineering Departments offer only one technical elective course related to the Heating, Ventilating, and Air Conditioning (HVAC) courses required for engineers. The Mechanical Engineering Departments assessed in the survey were in the state of Alabama, Arkansas, and Louisiana. Due to the small number of graduate seniors, most Mechanical Engineering Departments are unable to offer the HVAC related courses.

Proceedings of the 2003 ASEE Gulf-Southwest Annual Conference

The University of Texas at Arlington

Copyright@2003,American Societyfor Engineering Education 
Nationally, building energy training is currently only extended at universities experiencing a large number of students enrolled in the mechanical engineering program. Besides the limited number of HVAC training curriculum available in the United States, building technology has shown a dynamic improvement over the past twenty years. Today's advanced computer technology and modern automotive concepts of managing building energy $[4,5,6]$ require that HVAC engineers have more expertise than traditional training. HVAC engineers, require additional knowledge of the most recent building energy industry developments $[7,8]$ to fulfill their job function. The HVAC engineer's title has been transferred into the new title of Energy Engineers or Building Energy Managers.

For the past ten years, one of the growing interests in the building energy engineers and training is energy efficiency policy. As a result of the Energy Policy Act of 1992, and Executive Order 12902, stipulates that federal agencies are required to meet stringent energy efficiency targets mandated by the Executive Order [9]. In Louisiana, the Energy Management Act Number 1184 of the year 2001 required all state agencies to report their energy usage and costs on a biannual basis [10]. The purpose of this Act Number 1184 was to provide for development and implementation of a state energy management policy regarding all state-owned buildings and facilities in a manner which will minimize energy consumption and ensure that buildings and facilities are operated with maximum efficiency of energy use. As the Louisiana energy auditor for the past ten years, the authors discovered that two major reasons that most facilities have not implemented the use of energy efficient technologies in the past are: a) the budget constraints, and b) a shortage of skilled building energy managers and building engineers for operation and maintenance of modern new systems. There is a strong demand for the new college graduate highly skilled building energy engineers.

\section{New Master of Engineering at Southern University and A\&M College}

Since the spring semester of 2002, Southern University and A\&M College, located in Baton Rouge, Louisiana, has been granted approval to offer a new Master of Engineering (MEng) Program in the existing College of Engineering. The objective of this new MEng program is to prepare graduates for leadership positions in the engineering profession. Emphasis is placed on solving practical problems in industry and society, in general, for the advancement of technology and the benefit of mankind. The program has five interdepartmental and interdisciplinary specialty options.

Currently, the Environmental and Water Resources Engineering Option is in the Department of Civil Engineering. The Telecommunications and Computer Network Engineering, the Electronic Materials and Processing Engineering Options are in the Department of Electrical and Electronics. The Materials Science and Engineering, Thermal Science and Engineering Options are managed by the Department of Mechanical Engineering.

The MEng degree will be awarded upon completion of at least 36 semester credit hours beyond the bachelor's degree. This requirement includes thirty (30) credit hours for coursework and six (6) credit hours for an engineering project. All students in the MEng Program will provide 
specialized training and a solid foundation in areas such as statistics, numerical methods, engineering managements, and advanced computer applications, which are illustrated in Table A.

In addition, the program will require students to take six (6) technical elective courses (18 hours) in a specialty option, leading to an engineering project. The choice of technical electives will allow students to tailor their studies to specific interests via a specialty option. Technical elective courses may also be selected from outside a specialty option upon the approval of graduate student faculty advisor.

Table A. Required Core Courses for All Five Options

\begin{tabular}{|c|c|}
\hline Fall Semester & Spring Semester \\
\hline \hline Probability and Statistics for Engineers (CIEN 500) & Engineering Management (MEEN 570) \\
\hline $\begin{array}{c}\text { Numerical Methods For Engineering Applications } \\
\text { (MEEN 550) }\end{array}$ & $\begin{array}{c}\text { Advanced Computer Applications For Engineers } \\
\text { (ELEN 530) }\end{array}$ \\
\hline \hline
\end{tabular}

This will provide the opportunity for technical breadth or take advantage of interdisciplinary synergies within other areas. After completing a minimum of 18 semester credit hours of coursework, students can commence an engineering project. The proposed matrix for the technical elective courses is illustrated in Table B.

Table B. Matrix for Technical Elective Courses

\begin{tabular}{|c|c|c|}
\hline Fall Semester & Spring Semester & Summer Semester \\
\hline \hline Technical Electives 1 and 2 & Technical Electives 3 and 4 & Engineering Project \\
\hline \hline Technical Electives 5 and 6 & Engineering Project \\
\hline
\end{tabular}

\section{Building Energy Systems Option (BESO)}

Today's Energy Engineers or Building Energy Managers must take a broader scope of responsibilities of their facilities. There is greater requirement of the middle and upper level of energy manager to manage a large facility. In addition to the demand for implementation of energy conservation, Energy Managers are obligated to develop a future plan that alleviates risk through alternate energy sources, financial derivative, and overall management plan. Further, these managers must develop requested proposals, supervise the construction, measurement, and verification of the energy savings. Based on author's survey, currently undergraduate HVAC education is no longer adequate for modern HVAC or Energy engineers. There is limited graduate HVAC training available nationally in the southern portion of the United States. Due to the demand of modern new energy engineers and energy manager, the Building Energy Systems

Proceedings of the 2003 ASEE Gulf-Southwest Annual Conference

The University of Texas at Arlington

Copyright@2003,American Societyfor Engineering Education 
Group (BESG) was formally established in our Department of Mechanical Engineering on November 6, 2002. The BESG is affiliated with the Thermal Science Options in the Department of Mechanical Engineering at Southern University. Currently a total of five faculty members are available to provide technical assistance with building energy related projects at Southern University. Most of our faculty members are highly qualified professional engineers with emphases on Building Energy Conservation, Energy Audits, Commissioning, Monitoring and Verification. One of the key objectives is to develop a modern HVAC/Building Energy Systems curriculum. Our proposed Master of Engineering in Building Energy Systems Option (MEngBESO) is to fulfill the need in middle and upper level of energy managers. We are utilizing the newly approved MEng Program in the College of Engineering.

The MEng-BESO is a modified version of our Thermal Sciences and Engineering Option with training in Building Energy courses. The MEng-BESO is a non-thesis program. Under this program, a minimum of 36 semester credit hours of coursework and internship is required. We still have four required core courses. The proposed matrix for BESO is illustrated in Table C, and Table D. The MEng-BESO is open for the student from the Mechanical, Electrical, and Architectural Departments.

Table C. Matrix for Building Energy Systems Option

\begin{tabular}{|c|c|c|}
\hline Fall Semester & Spring Semester & Summer Semester \\
\hline Technical Electives 1 and 2 & Technical Electives 3 and 4 & Internship \\
\hline \hline Technical Electives 5 and 6 & Internship \\
\hline
\end{tabular}

Table D. Technical Elective Courses in Building Energy Systems Option

\begin{tabular}{|l|l|}
\hline No. & \multicolumn{1}{|c|}{ Spring Semester } \\
\hline \hline 1. & Thermal Environment Engineering \\
\hline 2. & Energy Management and Application \\
\hline 3. & Energy Management Systems and Direct Digital Control \\
\hline \hline 4. & Building System Performance Simulation Techniques and Control \\
\hline 5. & Alternative Energy Systems \\
\hline 6. & Preventive Maintenance and Security \\
\hline 7. & Building Contracting Project Management \\
\hline 8. & Co-generation \\
\hline \hline 9. & Air Quality Design and Application \\
\hline \hline 10. & Internship \\
\hline
\end{tabular}

\section{Conclusion}

Based on our study, some of the problems facing building HVAC education today have been discussed. There is little disagreement among the energy and HVAC leaders on lack of 
consensus agenda for the modern graduate HVAC education and research. In this regard, the authors would like to emphasize the importance of strengthening building energy curriculum in the advanced computer technology, energy conservation, energy management, and project management.

Our MEng-BESO developed to fulfill the demand for advanced technology training energy engineers, and building energy managers. The demand for this technology comes from several sources, such as the building industry, consultant firms, Energy Service Companies, governmental agencies, and education systems. However, the success of this program depends upon the university support and research funding from organizations such as DOE, NSF, ASEE, ASME, ASHRAE, and the AEE.

\section{References}

1. Meredith, D. B., "Current Demand for HVAC and R Graduates", ASHRAE TRAUS, Vol. 95, pp. 11781181.

2. Moriarta, Courtney, "The Next Generation of Energy Efficiency Professionals", State Energy Program, Rebuild America Conference, July 29-August 1, 2002.

3. Chen Chu-Chen, "Modern HVAC Engineers and Training". Tri-state Engineering Societies Annual Meeting, June 30-July 3, 2002.

4. Bushby, S.T., Newman, M., "BAC Net Today", ASHRAE Journal, pp. 10-18, October 2002.

5. Chen, Chu-Chen, Rideau, H.M., El-Khatib, A.M., and Joshi, G.A., "Vibration Diagnostic Analysis and HVAC Application", The Third International Symposium on HVAC, Shenzhen, China, Volume 2, pp. 850856, November 1999.

6. Behnken, J., "Building Automation for Multi-site facilities." ASHRAE 43(6), June 2001.

7. Kohl, R., "Commissioning HVAC Control Systems", ASHRAE Journal, 43 (12), pp. 27-50, December 2001.

8. Mathandhu, S. S., "Energy Conservation Showcase” ASHRAE 41(4), pp. 44-46, April, 1999.

9. Ginsberg, M., "New Direction in Federal Energy Management", $17^{\text {th }}$ World Energy Engineering Congress, pp. $555-562$

10. Moses, M., Thevenet, D., Manning, J.F., "How to Utilize the FM Database for Web-based Reporting of Utility Consumption", Louisiana Energy Management Workshop, November 2002.

\section{CHU-CHEN (C.C.) CHEN}

Dr. Chen is an Endowed Professor in Construction in the Department of Mechanical Engineering at Southern University and in A\&M College. He received a MSME from North Carolina State University in 1967, and a Doctor of Engineering degree from Texas A\&M University in 1985. He has served as an energy consultant for numerous energy related projects for the past thirty years. More than fifty (50) technical papers have been published and / or presented at regional, national, and international conferences. He has also performed more than four hundred (400) technical Energy Audits over the past ten years. As a registered professional engineer, he is a member of ASEE, ASME, and Pi Tau Sigma.

\section{CHUN LING HUANG}

Dr. Chun Ling Huang earned B.S. and M.S.degrees in mechanical engineering from Chung Yuan Christian University (CYCU) in Taiwan, and a Ph.D. degree in mechanical engineering from the University of Alabama (UA) at Tuscaloosa. He was a graduate teaching and research assistants at CYCU and UA before joining the faculty of Southern University in Baton Rouge (SUBR), Louisiana, in 1990. Currently, he is an associate professor of mechanical engineering in SUBR. He is a member of ASME and ASEE.

Proceedings of the 2003 ASEE Gulf-Southwest Annual Conference

The University of Texas at Arlington

Copyright@2003,American Society for Engineering Education 